\title{
Evaluation of Antiretroviral Therapy Initiated Among Pregnant Women Under Option B+ by Viral Load and CD4 Count Outcomes in Selected Hospitals of West Shewa Zone, Oromia Region, Ethiopia
}

This article was published in the following Dove Press journal:

HIVIAIDS - Research and Palliative Care

\author{
Dereje Bayissa Demissie (D) \\ Gizachew Abdissa Bulto ${ }^{2}$ \\ Wagi Tosisa Mekuria (D) $^{3}$ \\ Fikru Negassa Dufera (iD) \\ Eriste Nigussa Gamshe (D)' \\ 'Department of Neonatal Nursing, \\ St. Paul's Hospital Millennium Medical \\ College, Addis Ababa, Ethiopia; \\ ${ }^{2}$ Department of Midwifery, College of \\ Medicine and Health Sciences, Ambo \\ University, Ambo, Ethiopia; ${ }^{3}$ Department \\ of Medical Laboratory Sciences, College \\ of Medicine and Health Sciences, Ambo \\ University, Ambo, Ethiopia; ${ }^{4}$ Department \\ of Public Health, College of Medicine and \\ Health Sciences, Ambo University, Ambo, \\ Ethiopa
}

Background: Antiretroviral therapy (ART) is effective for the elimination of mother-to-child transmission (eMTCT) of human immunodeficiency virus (HIV) infection, reducing infant mortality and ensuring maternal virologic suppression, while pregnant women require test and treat under Option B+ programs. Therefore, the study aimed to assess the evaluation of antiretroviral therapy initiated among pregnant women under Option $\mathrm{B}+$ by viral load and CD4 count outcomes in selected hospitals of West Shewa Zone, Oromia Region, Ethiopia.

Methods: Hospital-based cross-sectional study design was employed to conduct the study at randomly selected hospitals providing Option $\mathrm{B}+$ services with routine viral load assessment by Oromia Regional Laboratory (ORL) from January 2016 to January 2017. Bivariate and multivariable logistic regression analyses were conducted to determine factors affecting the time to ART initiation following an HIV test and logistic regression was used to determine the correlation between time and treatment outcomes.

Results: The viral load suppression (VL $<1000$ copies $/ \mathrm{mL}$ ) was achieved in $31 \%$ and $58.7 \%$ of patients who were on ART treatment for $\leq 37$ months and longer than 38 months, respectively. It was identified that the mean viral load and CD4 count were 197.27 and 629.17, respectively, while $85.3 \%$ of the clients had their CD4 count increased from the baseline data. The study revealed that level of ART adherence, completion of full doses, compliance on appointments, duration of the ART uptake and baseline CD4 count were independent predictors of viral load suppression for women started on option $\mathrm{B}+$ and continued on lifelong ART. And this study also revealed that gestational age at ART start, maternal age in years and adherence on medication were independently associated with CD4 response among HIV pregnant women initiated for lifelong ART.

Conclusion: The study results demonstrated that for $89.7 \%$ of study respondents, viral load was suppressed of which $80.3 \%$ were undetectable $\left(\mathrm{VL}=0\right.$ copies $/ \mathrm{ml}^{3}$ and $85.3 \%$ had increased CD4 count). This study determined the factors associated with viral load suppression and CD4 count improvement. Therefore, these factors should be emphatically considered during Option $\mathrm{B}+$ program development and training to ensure CD4 count improvement and viral load suppression achievements.

Keywords: antiretroviral therapy, initiation pregnant women Option B +, viral load, CD4 count

\section{Background}

These trends, along with ART scale-up, have globally resulted in increased prevalence, with $36 \cdot 8$ million $(34 \cdot 8-39 \cdot 2)$ people living with HIV in 2017 . Prevalence
Correspondence: Dereje Bayissa Demissie

Email Dereje.bayissa@sphmmc.edu.et
HIV/AIDS - Research and Palliative Care 2020:12 127-134

127 
of HIV was highest in southern sub-Saharan Africa in 2017, and countries in the region had ART coverage ranging from $65 \cdot 7 \%$ in Lesotho to $85 \cdot 7 \%$ in eSwatini. Our forecasts showed that 54 countries will meet the UNAIDS target of $81 \%$ ART coverage by 2020 and 12 countries are on track to meet $90 \%$ ART coverage by $2030 .{ }^{1}$

Antiretroviral therapy (ART) coverage is much lower $(20 \%)$ in developing settings like Asia, Pacific, Eastern, and Northern Africa as compared to over $90 \%$ in Eastern and Central Europe and Caribbean. ${ }^{1}$ Findings of studies in other African countries like Zimbabwe, Tanzania, and Malawi suggest that Option $\mathrm{B}+$ is expensive, while, it is cost-effective in terms of averting infant infections improves the women' and infants' health outcomes. ${ }^{2,3}$

Despite the rollout of interventions such as the Option $\mathrm{B}+$ program, it is suggested that the HIV prevalence among women and new HIV pediatric infections remains disproportionately high especially in Sub-Saharan Africa. This is further aggravated by weak health systems which hinder the initiation and follow up of women initiating on lifelong ART. For example, low uptake of antenatal care (ANC) services, stigma and lack of disclosure negatively impact PMTCT programs. ${ }^{4}$ In Zambia, it is reported that HIV-infected women attending PMTC programs present to care late in pregnancy and many are lost to follow-up by 6-months postpartum. ${ }^{5}$ In this study, the focus was on pregnant women that initiated ART and received option $\mathrm{B}+$ services for at least 12 months. Therefore, this evaluated the viral load and CD4 count outcomes among HIV pregnant women that initiated ART on Option $\mathrm{B}+$ for at least 12 months at healthcare facilities in Ethiopia.

\section{Methods}

\section{Study Setting and Design}

Hospital-based cross-sectional study design was employed to conduct the study at randomly selected Hospitals providing Option $\mathrm{B}+$ services with routine viral load assessment by Oromia regional Laboratory (ORL) from January 2016 to January 2017 in west shoa zone, Oromia Regional State, Ethiopia. Ambo town which is the capital of the zone is located $114 \mathrm{~km}$ to the west of Addis Ababa the capital of the country. According to information from the zonal health office, the total population in the zone was estimated to be 2,381,079 of which 1,214,350 of them are female. Currently, the health system of the zone consists of 6 hospitals, 90 health centers and 447 health posts with $98 \%$ of potential health service coverage.
There are different governmental and nongovernmental organizations working on HIV/AIDS in the zone. There are 5 hospitals, namely Ambo hospital, Enchini Primary Hospital, Gedo Hospital, Gindaberet Hospital, Guder Primary Hospital and 21 health centers which are providing ART services for 8439 clients in West Shewa zone (Data from west Shewa zone health office, November 2016). HIV-positive pregnant women who initiated on ART under option B+ for 12 months and had viral load assessment were source population. All sampled pregnant HIV-positive women who initiated on ART under Option B + for at least 12 months and had their viral load determined from those selected health facilities in West Shoa zone were our study population.

\section{Sample Size Determination and Sampling Procedure}

The required sample size was determined using Stat calc of EPI INFO version 7.1 .0 statistical package with a $50 \%$ rate of viral suppression based on limited data with a precision of $5 \%$ and $95 \%$ confidence level. By using correction formula, since the total population was 1860 which was less than 10,000 , and by considering $5 \%$ non-response rate the final sample size was 334. All hospitals found in West Shoa Zone of Oromia region that providing ART services were identified and randomly selected by computer-generated methods to be included in the study. The number of study respondents was allocated proportionally to five hospitals based on their total number of ART clients' positive pregnant women who initiated ART under option $\mathrm{B}+$ for at least 12 months to participate in the study.

\section{Operational Definitions}

Treatment outcomes in the study concept were included desired results following therapy or treatment outcomes among pregnant women that initiated ART under Option $\mathrm{B}+$ programs for at least 12 months in Ethiopia which were

- CD4 count;

- Viral suppression (among women).

\section{Data Collection Tools and Procedures}

The data collection tools were structured questionnaire (translated to local language) and chart or medical records abstraction tool adopted from similar surveys and modified for the study. Questions in the chart abstraction were adopted from clinical management of clients receiving HIV care and treatment. Data on both the questionnaires 
and abstraction forms were collected by trained research assistants and data abstractors. At the completion of abstraction at the health facilities, tools were checked for completeness and completed tools were collected by the team leaders and stored in safe and locked cabinets accessed only by the researcher.

\section{Data Management and Analysis}

The returned questionnaires were checked for completeness, cleaned manually, coded and entered into EPI INFO 7.1.0 version and then transferred to SPSS windows version 20.0 for further analysis. Frequencies mean and the standard deviation was used to summarize descriptive statistics of the data and text, tables and graphs were used for data presentation. Bivariate analysis was used to check the association with the dependent variable. Variables which are found to have an association with the dependent variables at $\mathrm{P}$ value of less than 0.25 were then entered into Multiple Logistic regression for controlling the possible effect of confounders and finally, the variables which have significant association were identified on the basis of AOR, with $95 \% \mathrm{CI}$ and p-value to fit into the final regression model.

\section{Results}

The mean age of respondents was 30.78 years $(n=319)$ with a standard deviation of 6.56 years.

Their age ranged from 18 to 50 years; $77.4 \%$ of them were $\leq 35$ years.

Nearly two-third 233(73.0) of respondents were married, 155(48.6\%) were orthodox religion follower and 246 (77.1) of them belong to Oromo ethnic group. One-third $116(36.4 \%)$ of women have no formal education and 123 $(38.6 \%)$ of them were housewives (Table 1).

\section{Clinical Characteristics of Respondents}

From total respondents, 114(35.7\%) were staged under WHO stage 1 while starting ART and 146 (45.6\%) were staged under WHO stage 2. More than half 196(61.4\%) respondents had a CD4 count of 350 cells $/ \mu \mathrm{L}$ during initiation of ART and 271(85.3\%) of respondents had a latest CD4 count of $>350$ cells/ $\mu \mathrm{L}$ during data collection.

The mean CD4 counts baseline during initiated ART was 349.68 cells $/ \mu \mathrm{L}$, which ranges from (24 to 1012). Whereas $272(85.3 \%)$ of respondents had recent CD4 count $>350$ cells $/ \mu \mathrm{L}$, while 196 (61.4\%) had CD4counts $\leq 350$ cells $/ \mu \mathrm{L}$ baseline during initiated of ART.
Table I Socio-Demographic Characteristics of HIV+VE Pregnant Women-Initiated ART Under Option $\mathrm{B}+$ in Selected Health Facilities of West Zone Oromia, Ethiopia 2017 ( $n=319)$

\begin{tabular}{|l|l|l|}
\hline Variable & Category & Frequency (\%) \\
\hline Age of respondent & $\leq 26$ & $99(31.0)$ \\
& $27-30$ & $62(19.4)$ \\
& $31-35$ & $86(27.0)$ \\
& $36+$ & $72(22.6)$ \\
\hline Marital status: & Single & $41(12.9)$ \\
& Married & $233(73.0)$ \\
& Widow/widowed & $21(6.6)$ \\
& Divorced/Separated & $24(7.5)$ \\
\hline Religion & Orthodox & $155(48.6)$ \\
& Protestant & $146(45.8)$ \\
& Muslim & $18(5.6)$ \\
\hline \multirow{2}{*}{ Ethnicity } & Oromo & $246(77.1)$ \\
& Amhara & $46(14.4)$ \\
& Tigray & $14(4.4)$ \\
& Gurage & $13(4.1)$ \\
\hline \multirow{2}{*}{ Education } & Illiterate & $116(36.4)$ \\
& Read and Write & $62(19.4)$ \\
& I-8th grade & $93(29.2)$ \\
& $9-10$ tha grade & $30(9.4)$ \\
& Diploma and above & $18(5.6)$ \\
\hline Residence & Govt & $31(9.7)$ \\
& Merchant & $53(16.6)$ \\
& Private & $47(14.7)$ \\
& Housewife & $123(38.6)$ \\
& Farmers & $65(20.4)$ \\
\hline & Urban & $193(60.5)$ \\
& Rural & $126(39.5)$ \\
\hline
\end{tabular}

The majority of the respondents 207(64.9\%) were initiated on the recommended ART regimen for option $\mathrm{B}+$ which is TDF+3TC+EFV and none of the respondents was initiated on 2 nd line regimen (Table 2).

\section{Time to ART from HIV test}

Of total respondents, 101(31.7\%) were delayed (did not initiate ART on the same day) following HIV test.

\section{Viral Suppression}

The study results indicated that majority of the respondents $89.7 \%$ were suppressed of which $80.3 \%$ were undetectable $\left(\mathrm{VL}=0\right.$ copies $\left./ \mathrm{ml}^{3}\right)$. When dichotomized, 89.7\% ( $\mathrm{n}=286$ ) HIV pregnant women were suppressed with VL $<1000$ copies $/ \mathrm{mL}$ versus $10.3 \%(\mathrm{n}=33)$ that were not suppressed (VL $>1000$ copies $/ \mathrm{mL}$ ). The viral 
Table 2 Respondents' Clinical Characteristics HIV+VE Pregnant Women-Initiated ART Under Option $\mathrm{B}+$ in Selected Health Facilities of West Zone Oromia, Ethiopia 2017

\begin{tabular}{|c|c|c|}
\hline Variable & & Frequency (\%) \\
\hline $\begin{array}{l}\text { Time to ART from HIV } \\
\text { testing }\end{array}$ & $\begin{array}{l}\text { Same day ( } 0 \text { days) } \\
\text { Delay day I to } 8 \text { days) }\end{array}$ & $\begin{array}{l}218(68.3) \\
101(31.7)\end{array}$ \\
\hline $\begin{array}{l}\text { WHO Clinical stage at } \\
\text { ART start }\end{array}$ & $\begin{array}{l}\text { Clinical Stage I } \\
\text { Clinical Stage } 2 . \\
\text { Clinical Stage } 3 \\
\text { Clinical Stage } 4\end{array}$ & $\begin{array}{l}114(35.7) \\
146(45.8) \\
37(11.6) \\
22(6.9)\end{array}$ \\
\hline $\begin{array}{l}\text { WHO Treatment stage } \\
(\mathrm{WHO}-\mathrm{T})\end{array}$ & $\begin{array}{l}\text { T-Stage I } \\
\text { T-Stage } 2\end{array}$ & $\begin{array}{l}309(96.9) \\
10(3.1)\end{array}$ \\
\hline $\begin{array}{l}\text { CD4 at ART start/ } \\
\text { BalineCD4 }\end{array}$ & \multicolumn{2}{|c|}{$\begin{array}{l}\text { A respondent that had CD4 count at } \\
\text { Baseline }\end{array}$} \\
\hline & $\begin{array}{l}\leq 350 \text { cells } / \mu \mathrm{L} \\
>350 \text { cells } / \mu \mathrm{L}\end{array}$ & $\begin{array}{l}196(61.4) \\
123(38.6)\end{array}$ \\
\hline Current CD4 & $\begin{array}{l}\leq 350 \text { cells } / \mu \mathrm{L} \\
>350 \text { cells } / \mu \mathrm{L}\end{array}$ & $\begin{array}{l}47(14.7) \\
272(85.3)\end{array}$ \\
\hline \multirow{2}{*}{$\begin{array}{l}\text { Mean of Time on ART } \\
\text { in months was } 57.7 \\
\text { Ranges from } 6 \text { months } \\
\text { to I5I months On ART }\end{array}$} & & \\
\hline & $\begin{array}{l}\leq 37 \text { months } \\
38-70 \text { months } \\
7 I+\text { months }\end{array}$ & $\begin{array}{l}108(33.9) \\
108(33.9) \\
103(32.2)\end{array}$ \\
\hline Clinical Adherence & $\begin{array}{l}\text { Schedule } \\
\text { Unscheduled }\end{array}$ & $\begin{array}{l}309(96.9) \\
10(3.1)\end{array}$ \\
\hline $\begin{array}{l}\text { Adherence to } \\
\text { medication }\end{array}$ & $\begin{array}{l}\text { Good } \\
\text { Poor/Fair }\end{array}$ & $\begin{array}{l}306(95.9) \\
13(4.1)\end{array}$ \\
\hline ART Regimen & $\begin{array}{l}T D F+3 T C+E F V-I e \\
A Z T+3 T C+N V P-I c \\
T D F+3 T C+N V P-I f \\
A z t+3 t c+E F V-I d\end{array}$ & $\begin{array}{l}207(64.9) \\
93(29.2) \\
7(2.2) \\
12(3.8)\end{array}$ \\
\hline $\begin{array}{l}\text { ART regimen of the } \\
\text { mother on } \\
\text { Maternal PMTCT } \\
\text { intervention during } \\
\text { a recent pregnancy }\end{array}$ & $\begin{array}{l}\text { Yes } \\
\text { No }\end{array}$ & $\begin{array}{l}315(98.7) \\
4(1.3)\end{array}$ \\
\hline $\begin{array}{l}\text { Newly diagnosed and } \\
\text { started on ART during } \\
\text { a recent pregnancy }\end{array}$ & $\begin{array}{l}\text { Yes } \\
\text { Know HIV +ve on } \\
\text { ART }\end{array}$ & $\begin{array}{l}87(27.3) \\
232(72.7)\end{array}$ \\
\hline Time of initiation of ART & $\begin{array}{l}\text { ANC } \\
\text { Labour and Delivery } \\
\text { Post-Partum period }\end{array}$ & $\begin{array}{l}67(21) \\
15(4.7) \\
6(1.9)\end{array}$ \\
\hline
\end{tabular}

load suppression (VL $<1000$ copies $/ \mathrm{mL}$ ) was achieved in $31 \%$ and $58.7 \%$ of patients who were on ART treatment for $\leq 37$ months and longer than 38 months, respectively.

\section{CD4 Count Response}

The mean CD4 count baseline was 581 cells $/ \mu \mathrm{L}$ and recent mean CD4 count were $629.17 \mathrm{cells} / \mathrm{ml}^{3}$. Out of the total 319 respondents that were assessed for CD4 response, more than $85.3 \%$ had increased CD4 count from baseline, while only five individuals had no CD4 count change (the difference between the initial and last CD4 count was zero).

\section{Predictors of Viral Suppression at Multivariable Level}

This study identified that those women had been in WHO clinical stage one were 1.64 times $(\mathrm{AOR}=1.64,95 \% \mathrm{CI}$ : $1.36,2.036)$ more likely had suppressed viral load as compared to WHO stage two at baseline.

Women that missed doses in the past month were 0.505 times $(\mathrm{AOR}=0.505,95 \% \mathrm{CI}: 0.13$ to 0.721$)$ less likely to had suppressed viral load as compared to those that did not miss prescribed doses.

Women missed clinical appointment were 0.373 times (AOR $=0.373,95 \% \mathrm{CI}(0.062$ to 0.087$))$ less likely to had suppressed viral load as compared to scheduled attendants. For each additional increase in time to ART from HIV testing in months, HIV VL copies $/ \mathrm{mL}$ increased by 0.018 copies $/ \mathrm{mL}$ (95\% Confidence interval (CI) 0.002 to 0.035 , $\mathrm{p}=0.03$ ). Therefore, in this study, missing doses in the past month, missing appointments, baseline CD4 and maternal months on ART were statistically significant (see Table 3).

\section{Predictors of CD4 Count Response at the Multivariable Level}

Out of 319 respondents included in the final model $(\mathrm{p}=0.001)$, increased gestational age at ART start, maternal age in years and adherence on medication were independently associated with CD4 response or immunological outcomes among HIV pregnant women initiated for lifelong ART.

An improved CD4 response was associated with increased gestational age at ART start 106 times $(\mathrm{AOR}=$ 106.508 , 95\% CI (25.238 to 186.472$)$ ) more likely as compared not initiated early gestational age.

Alternatively, decreasing CD4 count was associated with increased age $(\mathrm{AOR}=-11.156,95 \% \mathrm{CI} ;-21.183$ to $-1.128)$ and fair/poor adherence to medication $(\mathrm{AOR}=$ $-121.931,95 \%$ CI $(-227.86$ to -16.001$)$

Variables that were not independently associated with CD4 response included time to ART following HIV testing, missed doses in the past month and parity (see Table 4). 
Table 3 Predictors of Viral Load Suppression of HIV+VE Pregnant Women-Initiated ART Under Option B+ in Selected Health Facilities of West Zone Oromia, Ethiopia 2017

\begin{tabular}{|l|l|l|l|}
\hline Variable & Category & AOR (95\% Cl) & P-value \\
\hline WHO clinical stage & $\begin{array}{l}2 \text { (Two) } \\
\text { I(One) }\end{array}$ & $\begin{array}{l}1.64(1.36,2.036) \\
\text { (reference) }\end{array}$ & 0.023 \\
\hline Adherence to ART drugs & $\begin{array}{l}\text { Good } \\
\text { Fair/Poor }\end{array}$ & $\begin{array}{l}\text { (reference) } \\
0.505(0.13 \text { to } 0.721)\end{array}$ & 0.000 \\
\hline Time to initiated ART & $\begin{array}{l}\text { Delayed } \\
\text { On the same day }\end{array}$ & $\begin{array}{l}0.14(0.002 \text { to } 0.035) \\
\text { (reference) }\end{array}$ & 0.030 \\
\hline Missed clinical appointment/schedule & $\begin{array}{l}\text { Schedule } \\
\text { Unscheduled }\end{array}$ & $\begin{array}{l}\text { (reference) } \\
0.373(0.062 \text { to } 0.087)\end{array}$ & 0.043 \\
\hline Missed Doses & $\begin{array}{l}\text { Yes } \\
\text { No }\end{array}$ & $\begin{array}{l}\text { (reference) } \\
0.38 \text { (0.04 to 0.280) }\end{array}$ & 0.02 \\
\hline
\end{tabular}

Table 4 Association Between Independent Factors and CD4 Response of HIV+VE Pregnant Women-Initiated ART Under Option B+ in Selected Health Facilities of West Zone Oromia, Ethiopia 2017

\begin{tabular}{|l|l|l|}
\hline Variable & $\mathbf{9 5 \%} \mathbf{~ C l}$ & P-value \\
\hline Gestation age & $106.508(25.238$ to 186.472$)$ & 0.011 \\
Age & $-11.156(-21.183$ to -1.128$)$ & 0.029 \\
Fair/poor adherence & $-121.931(-227.86$ to -16.001$)$ & 0.024 \\
\hline
\end{tabular}

\section{Discussion}

Time on ART is an important predictor of treatment outcomes among women who initiate ART under option $\mathrm{B}+$. Most importantly, the initial period during ART initiation is associated with poor outcomes like reduced viral suppression. The proportion of suppressed respondents with $\mathrm{VL}<1000$ copies/mL was lowest $31 \%$ among those on ART for $<37$ compared to those on ART for 38-70 months $58.7 \%$ and the majority of the respondents $89.7 \%$ were suppressed of which $80.3 \%$ were undetectable $(\mathrm{VL}=0$ copies $/ \mathrm{ml}^{3}$ ). Detectable VL or none suppression is highest among women that enrol on option $\mathrm{B}+$ with $\leq 4$ months of ART. ${ }^{6,7}$ The results of this study emphasized the need to intensify support for HIV pregnant women on option B+ during the early months of ART initiation.

Most of the respondents in the study at the start of ART presented with high CD4 count with a median of 349.68 cells $/ \mu \mathrm{L}$ and IQR (1-1012) and less advanced WHO Treatment stage with $96.9 \%(n=309)$ staged as WHO stage 1 and $3.1 \%(n=10)$ as stage 2 , report that $70.5 \%$ of breastfeeding and pregnant women on option $\mathrm{B}+$ in Northeast Ethiopia initiate ART with WHO clinical stage 1 and $6.6 \%$ with stage $2 .{ }^{8}$ In Haiti, $92 \%$ of women have clinical stage 1 or 2 among the $68 \%$ of option $\mathrm{B}+$ clients. ${ }^{9}$ This study $11.6 \%$ were WHO stage 3 and $6.9 \%$ were stage 4 . In Malawi report that $80.2 \%(n=5991)$ women on option $\mathrm{B}+$ have WHO clinical stage $1,3.9 \%(n=1294)$ WHO stage $2,10.2 \%(n=2,765)$ WHO stage 3 and $2.9 \%(n=214)$ with stage 4 and other study, more women in the pre-option $\mathrm{B}+$ cohort have WHO stage 3 or 4 at the time of ART initiation compared to those on option $\mathrm{B}+(11.9 \%$ versus $1.1 \%, \mathrm{p}<0.001){ }^{10,11}$

In this study, 61.4\% $(n=196)$ respondents had CD4 counts $<350$ cells/ul at baseline which implied that there were women on option $\mathrm{B}+$ that initiated ART with a low CD4 count and recent last six-month CD4 count indicated that only $14.7 \%(n=47)$ were less than 350 cells/ul this leads to improved immune recovery. Women on option $\mathrm{B}+$ that initiate ART with low CD4 count at ART start, therefore, would benefit from getting a baseline CD4 cell count.

Concerning VL suppression, the study results revealed a median viral load (copies $/ \mathrm{mL}$ ) of 3.62 copies $/ \mathrm{mL}$ with IQR (3.00-12.01copies $/ \mathrm{mL}$ ) compared to a median viral load (copies/mL) of 4.3 (2.0-5.7; 3.8-4.7) among women that are ART naïve and experienced. ${ }^{5}$ The difference could be explained by the difference in study respondents. The study consisted of ART naïve pregnant women while the study had both naïve and ART-experienced participants and ARV-naive pregnant women are more likely to achieve viral loads $<1000$ copies/mL compared to those who are ARV-experienced. ${ }^{6}$

The study results also indicated that majority of the women 89.7\% ( $\mathrm{n}=286)$ HIV pregnant women have suppressed with $\mathrm{VL}<1000$ copies/mL compared to $10.3 \%(\mathrm{n}=33)$ that were not suppressed $(\mathrm{VL}>1000$ copies $/ \mathrm{mL}$ ). The high viral suppression 
rates were comparable to another study conducted in Uganda with $96 \%$ (67/70) pregnant and lactating women on option $\mathrm{B}+$ suppressed at 6 months, 93.1\% (174/187) at 12 months and $95.8 \%(479 / 500)$ at 24 months with suppression $\mathrm{VL}<1000$ copies $/ \mathrm{mL}^{12}$ and also report a viral suppression rate (VL $<1000$ copies $/ \mathrm{mL})$ of $90 \%(\mathrm{n}=448)$ among pregnant and breastfeeding women enrolled on option $\mathrm{B}+$ in 13 large health facilities in Malawi. ${ }^{10}$

In this study, decreased CD4 count or immunologic failure was associated with fair/poor adherence to medication which was similar with the log of change of CD4 cell count among patients with fair adherence is $2.9 \%$ less than patients with good adherence and the log of change of CD4 cell count among patients with poor adherence at visiting time is $5.7 \%$ less than those of good adherent patients. ${ }^{13}$ In this study, all patients had access to free ART and laboratory tests including VL assessment and CD4 count measurement. ${ }^{13}$

In Uganda, poor maternal adherence to ART is independently associated with infant HIV infection (adjusted hazard ratio [aHR] 1.88, 95\% CI 1.30-2.73, p<0.001) among women on option $\mathrm{B}+.{ }^{14}$ Alternatively in a systematic and meta-analysis study in low and middle-income countries report that adherence is higher during pregnancy $(75.7 \%$, 95\% CI 71.5-79.7\%) compared to the postpartum $(53.0 \%$, $95 \% 32.8 \%$ to $72.7 \%)(\mathrm{p}=0.005)$ period. ${ }^{15}$ These differences could be caused by the different regimen used in the two studies. Moreover, a regimen with reduced pill burden, easier dosing, and better tolerability may also enhance ART adherence among pregnant women. ${ }^{16}$ Various PMTCT programmes use different methods for measuring adherence. However, common measures include self and proxy reports, pill counts, pharmacy refills, electronic drug monitoring, virologic markers (CD4 counts, viral loads) and blood draws for drug concentrations. Higher proportion of HIVpositive pregnant women on option $\mathrm{B}+$ which of $87.1 \%(95 \%$ CI 82.6-90.7\%) had adequate adherence in Tigray, northern Ethiopia, which was almost similar observation with current study finding revealed that $95.9 \%$ (306) of women on option $\mathrm{B}+$ had good adherence. ${ }^{17} \mathrm{~A}$ much higher proportion of pregnant and breastfeeding women on option B+ $(91.4 \%)$ have good adherence to ART ( $\geq 95 \%$ adherence) (MSPH 2015:10). Ensuring adequate adherence to ART among women who initiate lifelong ART on option $\mathrm{B}+$ is essential for an improved immunological response. This would consequently contribute to the reduction of MTCT. Strategies targeting to address issues that hinder adherence among HIVpositive pregnant women on ART are essential for improved immunological outcomes.
Most studies indicated similar findings in which older individuals are more likely to have immunological failure compared to those that are younger. In Ethiopia, report that immunological treatment failure is associated with old age. ${ }^{18}$ Furthermore, in North-West Ethiopia, each unit increase in years is associated with a $3.3 \%$ cell $/ \mathrm{mm}^{3}$ decrease in the log of change of CD4 cell count $(0.0098$, 0.0899); $\mathrm{p}=0.0264 .{ }^{13}$ Patients with lower CD4 cell count at ART initiation and more advanced age ( $>40$ vs $<40$ years) demonstrate a decline in CD4 cell count from baseline to 12, 24, and 36 months of follow-up. ${ }^{14}$

Findings in seven countries in Sub-Saharan Africa and Thailand suggest that lower CD4 cell increase is independently associated with male sex, older age and lower CD4 cell count at ART initiation, age, baseline CD4+ count, initial regimens, changes in regimen and inclusion of a cotrimoxazole prophylaxis are associated with CD4+ $\mathrm{T}$ cell count recovery. ${ }^{4,6}$ In North-West Ethiopia, higher baseline CD4 count, younger age, working functional status, and time on treatment contribute positively to the increase of the CD4 cell count. ${ }^{13}$ In Abidjan, immunological failure is three times higher in patients $\geq 15$ years of age that had a baseline CD4 cell count of $\geq 200 / \mathrm{mm}^{3}$. 19

While the study results did not elicit any statistically significant results between time to ART start following HIV testing and immunologic response, the results indicated that delay in initiating ART following HIV testing among pregnant women on option $\mathrm{B}+$ is associated with decreasing CD4 count response which is in agreement with some studies which suggest that delayed ART initiation is associated with poor treatment outcomes.

On the contrary, it is suggested that immunological treatment failure is associated with lower baseline CD4 count and higher educational status. ${ }^{18}$ According to the study conducted in Addis Ababa, it is showed that women with lower CD4 count before ART initiation $<200$ cells $/ \mathrm{mm}^{3}$ are 0.023 times less likely to achieve good immunological outcome compared to those with CD4 count $\geq 200$ cells $/ \mathrm{mm}^{3}$ $(\mathrm{AOR}=0.023,95 \% \mathrm{CI}=(0.003-0.190), \mathrm{p}=0.000)$ among women who start HAART before or during pregnancy in a Hospital in Addis Ababa. ${ }^{20}$

\section{Conclusion and Recommendation}

The study results demonstrated that for $89.7 \%$ of study respondents, viral load was suppressed of which $80.3 \%$ were undetectable $\left(\mathrm{VL}=0\right.$ copies $/ \mathrm{ml}^{3}$ and $85.3 \%$ had increased CD4 count). 
This study determined that factors associated with viral load suppression and CD4 count improvement. Therefore, these factors should be emphatically considered during Option $\mathrm{B}+$ program development and training to ensure $\mathrm{CD} 4$ count improvement and viral load suppression achievements.

The results of this study were also guided policy and current protocol modification in the area of Option $\mathrm{B}+$ implementation especially in low-resource countries that face challenges due to weak health systems and to contextualize it.

Analyzing the relationship between factors that influence ART initiation and treatment outcomes among these women through empirical processes was to provide awareness, guidance, and suggestions on viable approaches or strategies that health providers can employ to support women and their infants during ART initiation.

Ministry of Health of Ethiopia would be better to decentralize ART laboratory services to zonal level to increase accessibility of CD4 count and viral load monitoring timely for better treatment outcomes.

Trained peer support groups established to support women that enrol on lifelong ART.

Improved partner participation and support to women enrolled in Option $\mathrm{B}+$ programmes.

Male partners support the women to initiate and adhere to lifelong ART.

Prospective studies that aim at further understanding the factors associated with treatment outcomes like viral change, LTFU and immunological outcomes among women who initiate on lifelong ART including the outcomes among children are beneficial in developing strategies to further support women on option $\mathrm{B}+$.

\section{Abbreviations}

ANC, Antenatal care; ART, Antiretroviral therapy; AZT, Zidovudine; DNA, Deoxyribonucleic Acid; EFV, Efavirenz; eMTCT, Elimination of Mother-to-child transmission; HBM, Health Belief Model; HIV, Human immunodeficiency virus; $\mathrm{MoH}$, Ministry of Health; MTCT, Mother-to-child transmission; NVP, Nevirapine; PCR, Polymerase chain reaction; PMTCT, Prevention of Mother-to-child transmission; TDF, TenofovirDisoproxilFumarate; UNAIDS, Joint United Nations Programme on HIV/AIDS; WHO, World Health Organization; 3TC, Lamivudine.

\section{Data Sharing Statement}

All data underlying the findings described in this manuscript fully available without restriction and if the article is accepted for publication, the data availability statement will be published as part of the final article. There is no legal and/or ethical organization imposing restriction on this research article. Authors have no special access privileges to the data.

\section{Ethics and Consent Statement}

Ethical clearance was obtained from the Ethical review committee of Ambo University CMHS (CMHS-R219 12019). Formal letter of cooperation was written to respective hospitals/health centres. Moreover, prior to commencing the study, a written informed consent was obtained from each respondent before data collection. In addition to this parental written consent was found from a parent of respondent. Confidentiality was maintained by omitting their name, and personal identification of participant was not compelled to the study. The right to refuse was respected and information collected from this research project was kept confidential and the collected information was stored in a file, without the name of the study participant. All participants provided written informed consent, and that this study was conducted in accordance with the Declaration of Helsinki. Consent for publication: Ambo University and Authors agreed for publication in a reputable journal. (Agreement Ref number: CMHSR219/2019).

\section{Acknowledgments}

We are grateful to the Department of Nursing and medical staffs for their constructive comments and continuous encouragement starting from topic selection to the development of this research proposal. We also want to acknowledge Ambo University, College of medicine and health sciences for giving us this opportunity. We are grateful for all Mothers attending Prevention of Mother to Child Transmission in West Shoa Zone Health Facilities, Data collectors and supervisor for their valuable contribution and support. Last not list to West zone Health office.

\section{Author Contributions}

All authors made substantial contributions to conception and design, acquisition of data, or analysis and interpretation of data; took part in drafting the article or revising it critically for important intellectual content; gave final approval of the version to be published; and agree to be accountable for all aspects of the work. 


\section{Disclosure}

The authors declare that they have no competing interests including financial or funding.

\section{References}

1. Frank TD, Carter A, Jahagirdar D, et al. Global, regional, and national incidence, prevalence, and mortality of HIV, 1980-2017, and forecasts to 2030, for 195 countries and territories: a systematic analysis for the global burden of diseases, injuries, and risk factors study 2017. Lancet HIV. 2019;6(12):e831-e859. doi:10.1016/S23523018(19)30196-1

2. Joint United Nations Programme on HIV/AIDS. Global report: UNAIDS report on the global AIDS epidemic 2013. Geneva: Joint United Nations Programme on HIV/AIDS; 2013.

3. Gopalappa C, Stover J, Shaffer N, Mahy M. The costs and benefits of Option $\mathrm{B}+$ for the prevention of mother-to-child transmission of HIV. AIDS. 2014;28:S5-14. doi:10.1097/QAD.0000000000000083

4. Fasawe O, Avila C, Shaffer N, et al. Cost-effectiveness analysis of Option $\mathrm{B}+$ for HIV prevention and treatment of mothers and children in Malawi. PLoS One. 2013;8(3):e57778. doi:10.1371/journal.pone.0057778

5. Aizire J. G Fowler M, M Coovadia H. Operational Issues and Barriers to Implementation of Prevention of Mother-To-Child Transmission of HIV (PMTCT) Interventions in Sub-Saharan Africa. Curr HIV Res. 2013;11(2):144-159.

6. Scott CA, Iyer HS, Bwalya DL, et al. Uptake, outcomes, and costs of antenatal, well-baby, and prevention of mother-to-child transmission of HIV services under routine care conditions in Zambia. PLoS One. 2013;8(8):e72444. doi:10.1371/journal.pone.0072444

7. Gourlay A, Birdthistle I, Mburu G, Iorpenda K, Wringe A. Barriers and facilitating factors to the uptake of antiretroviral drugs for prevention of mother-to-child transmission of HIV in sub-Saharan Africa: a systematic review. J Int AIDS Soc. 2013;16(1):18588. doi:10.7448/IAS.16.1.18588

8. Mitiku I, Arefayne M, Mesfin Y, Gizaw M. Factors associated with loss to follow-up among women in Option B+ PMTCT programme in northeast Ethiopia: a retrospective cohort study. J Int AIDS Soc. 2016;19(1):20662. doi:10.7448/IAS.19.1.20662

9. Gill MM, Hoffman HJ, Bobrow EA, et al. Detectable viral load in late pregnancy among women in the Rwanda option B+ PMTCT program: enrollment results from the Kabeho study. PLoS One. 2016;11(12):e0168671. doi:10.1371/journal.pone.0168671

10. Myrtil MP, Puttkammer N, Gloyd S, et al. ART attrition across health facilities implementing Option B+ in Haiti. $J$ Int Assoc Provid AIDS Care (JIAPAC). 2018;17:2325958218774037. doi:10.1177/23259582 18774037
11. Haas AD, Tenthani L, Msukwa MT, et al. Retention in care during the first 3 years of antiretroviral therapy for women in Malawi's option $\mathrm{B}+$ programme: an observational cohort study. Lancet HIV. 2016;3(4):e175-82. doi:10.1016/S2352-3018(16)00008-4

12. Kamuyango AA, Hirschhorn LR, Wang W, Jansen P, Hoffman RM. One-year outcomes of women started on antiretroviral therapy during pregnancy before and after the implementation of Option $\mathrm{B}+$ in Malawi: a retrospective chart review. World J AIDS. 2014;4(3):332. doi:10.4236/wja.2014.43039

13. Ayanga RA, Namukwaya Z, Lugoloobi EN, et al. Virological Response Among HIV-Infected Pregnant and Lactating Women Initiated on Option $B+$ Attending the PMTCT Program at Mulago National Hospital. Kampala, Uganda: International AIDS Society; 2015.

14. Seyoum A, Ndlovu P, Temesgen Z. Joint longitudinal data analysis in detecting determinants of CD4 cell count change and adherence to highly active antiretroviral therapy at Felege Hiwot teaching and specialized Hospital, North-west Ethiopia (Amhara Region). AIDS Res Ther. 2017;14(1):14. doi:10.1186/s12981-017-0141-3

15. Maskew M, Brennan AT, Westreich D, McNamara L, MacPhail AP, Fox MP. Gender differences in mortality and CD4 count response among virally suppressed HIV-positive patients. $J$ Womens Health. 2013;22(2):113-120. doi:10.1089/jwh.2012.3585

16. Ngarina M, Tarimo EA, Naburi H, et al. Women's preferences regarding infant or maternal antiretroviral prophylaxis for prevention of mother-to-child transmission of HIV during breastfeeding and their views on Option B+ in Dar es Salaam, Tanzania. PLoS One. 2014;9(1):e85310. doi:10.1371/journal.pone.0085310

17. Nachega JB, Mugavero MJ, Zeier M, Vitória M, Gallant JE. Treatment simplification in HIV-infected adults as a strategy to prevent toxicity, improve adherence, quality of life and decrease healthcare costs. Patient Prefer Adherence. 2011;5:357. doi:10.2147/PPA.S22771

18. Tsegaye D, Deribe L, Wodajo S. Level of Adherence and Associated Factors to Option B+ PMTCT Among Pregnant and Lactating Mothers in Selected Government Health Facilities of South Wollo Zone. Amhara Region, North East Ethiopia; 2016.

19. Teshome W, Assefa A. Predictors of immunological failure of antiretroviral therapy among HIV infected patients in Ethiopia: a matched case-control study. PLoS One. 2014;9(12):e115125. doi:10.1371/journal.pone. 0115125

20. Ijigu GM, Gemeda DH, Angamo MT. Maternal immunologic and clinical response to antiretroviral therapy initiation before or during pregnancy in HIV-1 infected women and associated factors in Southwest Ethiopia. Gulhane Med J. 2015;57(2). doi:10.5455/gulhane.155305

\section{Publish your work in this journal}

HIV/AIDS - Research and Palliative Care is an international, peerreviewed open-access journal focusing on advances in research in HIV, its clinical progression and management options including antiviral treatment, palliative care and public healthcare policies to control viral spread. The manuscript management system is completely online and includes a very quick and fair peer-review system, which is all easy to use. Visit http://www.dovepress.com/testimonials.php to read real quotes from published authors. 